Acta Protozool. (2019) 58: 201-215 www.ejournals.eu/Acta-Protozoologica doi:10.4467/16890027AP.19.018.12020 PROTOZOOLOGICA

\title{
Testate Amoebae in Karst Caves of the Dinaric Arc (South-Eastern Europe) with a Description of Centropyxis bipilata sp. nov.
}

urn:Isid:zoobank.org:pub:14C0B57B-D69D-4A50-8AD3-24587BAF4241

\author{
Najla Baković ${ }^{1,2,3}$, Ferry J. Siemensma4, Robert Baković1,2, Josip Rubinić5 \\ ${ }^{1}$ ADIPA - Society for Research and Conservation of Croatian Natural Diversity, Orehovečki ogranak 37, 10040 Zagreb, Croatia \\ ${ }^{2}$ Croatian Biospeleological Society, Demetrova 1, 10000 Zagreb, Croatia \\ ${ }^{3}$ DVOKUT-ECRO Ltd, Trnjanska 37, 10000 Zagreb, Croatia \\ ${ }^{4}$ Julianaweg 10, 1241VW Kortenhoef, the Netherlands \\ ${ }^{5}$ University of Rijeka, Faculty of Civil Engineering, Radmile Matejčić 3, 51000 Rijeka, Croatia
}

\begin{abstract}
Karst freshwater caves are subterranean habitats characterized by the constant absence of light and relatively small variations of temperature and air humidity. They are mostly food deprived environments, with the exception if large bat colonies are present or if they are intensively supplied with organic matter by sinking rivers. Even though these habitats are often described as harsh, they have enabled the evolution of highly specialized and often endemic animals. The cave eukaryotic micro-organisms, on the other hand, are scarcely researched. The results of research of testate amoebae in the caves of the Dinaric arc detected 23 species, 12 of which were first found in caves. Also, a description of Centropyxis bipilata sp. nov. is presented. This species is clearly distinguished from other described species based on shell size, the presence of two struts and the usually dark ring around the aperture. Testate amoebae were registered on aquatic and terrestrial cave sediments and transitional habitats (like hygropetric and wet walls). The most frequent species within the samples were: Trinema lineare, Cryptodifflugia oviformis and Centropyxis bipilata sp. nov. Maximum diversity of testate amoebae was registered in Ponor Kovači with twenty species. In $24.4 \%$ of the investigated samples microphototrophs were found, implying good surface-subsurface connectivity that could also affect testate amoebae diversity. This research showed that caves are underestimated habitats that can provide us with new data about the testate amoebae biogeography and diversity.
\end{abstract}

Keywords: cave testate amoebae, karst cave connectivity, cave protists, phototrophic organisms in caves, aphotic habitats.

\section{INTRODUCTION}

Testate amoebae occur worldwide in terrestrial and freshwater habitats, but most frequently in moist acid

Address for correspondence: Najla Baković, ADIPA - Society for Research and Conservation of Croatian Natural Diversity, Orehovečki ogranak 37, 10040 Zagreb, Croatia; E-mail: najla.bakovic@gmail.com soils and peats, with high organic content and low nutrient turnover (Smith et al. 2008). For a long time testate amoebae have been used to describe changes of water tables during bog development (e.g. Hoogenraad and De Groot 1940, Mitchell et al. 2008) and in investigations of the ageing of lakes (Meisterfeld 2000a). In the last decennia, there has been a growing interest in soil communities (Bobrov 2019, Smith et al. 2008), but the presence of testate amoebae in caves is largely uncharted territory. 
The study of protozoa in karst caves started in the nineteenth century (Vandel 1965). Even though caves are, at first glance, harsh and barren, these habitats support a unique fauna ranging from various invertebrates to amphibians. The spatial isolation of these organisms and specific environmental conditions (absence of light, small variations of air temperature and high humidity, low food input) lead to the evolution of specialized and mostly endemic fauna (Culver and Pipan 2009). The Dinaric arc is especially rich in species and it is considered as one of the hotspots of subterranean biodiversity (Culver and Sket 2000). Specialized and endemic subterranean fauna is imposing the question: are there also specialized subterranean protists?

This question has challenged many researchers to enter the caves even though these are often very technically demanding environments (vertical objects, narrow channels, etc.) where specialized speleological skills are needed. Unfortunately, only scarce results, collected by various researchers, exist. Mostly, they were the result of single sampling efforts, but Chibisova (1967) and Decloitre (1955) provided a surprising amount of data on the morphology of collected individuals. Chibisova (1967) described a new species of testate amoebae from caves, Cyclopyxis bathystoma, later considered one of the synonyms of Cyclopyxis kahli (Foissner et al. 1995). Some authors have also described new forms/varieties of testate amoebae from caves (Chibisova 1967, Decloitre 1955, Delhez and Chardez 1970). Gittleson and Hoover (1970) even wrote a simple key for the identification of common species in caves.

Most researchers have concluded that testate amoebae from caves comprised already described and mostly eurybiont species (e.g. Gittleson and Hoover 1969, Golemansky and Bonnet 1994). Different caves usually harbor a lot of similar species. When comparing the biodiversity within different caves, Gittleson and Hoover (1970) found that $50 \%$ of the detected species were also found in two or more researched caves which is in accordance with the results of other researchers mentioned in the same article.

Mazei et al. (2012) studying caves in Russia and Italy observed different dominant species in different regions. They noticed that some species common in the caves were absent in the surface habitats in the same regions. The species richness of testate amoebae, observed in their research, was higher in caves with diverse habitats.

Regarding Golemansky and Bonnet (1994), the abundance of testate amoebae in freshwater and some terrestrial habitats (clay deposits) in caves is low. The highest abundance of testate amoebae is found in sediments that are rich in organic matter (e.g. bats guano), moonmilk and aggregations of mycelia on wood material. Some authors mention that testate amoebae were not always detected in samples, which implies that their populations could also be very low (Delhez and Char$\operatorname{dez} 1970)$.

The goal of this study was to record the biodiversity of testate amoebae in various aphotic microhabitats of karst caves and to discuss some ecological implications with regard to the surface-subsurface connectivity in the karst terrain of the Dinaric arc.

\section{MATERIALS AND METHODS}

\section{Research location}

Samples were collected in freshwater karst caves located in South-Eastern Europe in the territories of Croatia and Bosnia and Herzegovina (Tab. 1, Fig. 1). These caves were formed in carbonate rocks such as limestones and dolomites. Regarding their hydrology conditions, they include sinkholes, caves that are subjected to occasional or constant endogenous flooding, and caves that are not showing significant water flows. The length of the researched caves range from tens of meters to thousands of meters. Bats' guano was occasionally present in some caves, but mostly near the cave entrances.

Table 1 shows the names and locations of the researched caves, the number of collected samples and sampling dates. The cave numbers 1-18 (Tab. 1) were in the main focus of this study: statistical analysis was performed on the data from these caves and also a detailed analysis of other biological data has been carried out. The cave numbers 19-27 (Tab. 1) represent additional locations where Centropyxis bipilata sp. nov. was found during unpublished research by N. Baković and R. Baković (details not mentioned here).

\section{Sampling and sample treatment}

All samples were collected in karst cave habitats out of the reach of day light (aphotic cave zone). Only the Jama Baredine cave is a touristic (show) cave with installed electric lights, open in the spring, summer and autumn months, while other caves are not open to the public.

Sampling of freshwater sediments: Samples from the water pools (calcite pools, some subterranean lakes and stream sediments, pools in deposits of cave sediments) were collected by suctioning the bottom layer of water and sediment with plastic pipettes and by transferring samples into plastic bottles. Floating sediment on the surface of subterranean water pools was collected directly into plastic bottles. Sediments from running and stagnant groundwater were taken directly by scooping the sediment with plastic bottles.

Sampling of transitional habitats: At locations where the water layer was too thin for pipette sampling (wet walls, hygropetric, bacterial biofilm on cave walls), the substrate was rubbed with plastic brushes. The sediment retained on the brush was then washed in 
Table 1. Cave locations

\begin{tabular}{|c|c|c|c|c|c|c|}
\hline $\begin{array}{l}\text { No. } \\
\text { of the cave }\end{array}$ & Name & $\begin{array}{l}\text { Short } \\
\text { name }\end{array}$ & $\begin{array}{l}\text { Geographical } \\
\text { location* }\end{array}$ & $\begin{array}{l}\text { Sampling } \\
\text { date }\end{array}$ & $\begin{array}{l}\text { No. of collected } \\
\text { samples }\end{array}$ & $\begin{array}{l}\text { Distance of sampling } \\
\text { site from the cave en- } \\
\text { trance }(\mathrm{m})\end{array}$ \\
\hline \multicolumn{7}{|c|}{ Research locations in main focus of this study } \\
\hline 1. & Bibićka & BIB & Munjasi, Trošmarija, HRV & 09/2012 & 1 & 35 \\
\hline 2. & Bilobrkova špilja & BIL & Bilobrci, Viničko polje, Vinica, B\&H & $09 / 2014$ & 2 & 60 \\
\hline 3. & Čavlinka & ČAV & Muškovci, Obrovac, HRV & 08/2016 & 1 & 30 \\
\hline 4. & Dahna & DAH & Omerovići, Tomislavgrad, B\&H & $\begin{array}{l}09 / 2013 \\
09 / 2014 \\
09 / 2018\end{array}$ & $\begin{array}{l}6 \\
3 \\
2\end{array}$ & $100-230$ \\
\hline 5. & Dobra & DOB & Vrilo, Prisoje, Tomislavgrad; B\&H & 09/2014 & 1 & 32 \\
\hline 6. & Jama Baredine & BAR & Nova Vas, Poreč, HRV & $09 / 2018$ & 3 & 290 \\
\hline 7. & Jopićeva špilja & JOP & Podgorje Krnjačko, Krnjak, HRV & $03 / 2012$ & 2 & $500-700$ \\
\hline 8. & Lisičja špilja & LIS & Omerovići, Tomislavgrad, B\&H & 08/2018 & 3 & $32-40$ \\
\hline 9. & Listvača & LTV & Grabovica, Tomislavgrad, B\&H & $08 / 2018$ & 2 & 70 \\
\hline 10. & Ponor Kovači & KOV & Kovači, Tomislavgrad, B\&H & $\begin{array}{l}09 / 2014 \\
08 / 2018\end{array}$ & $\begin{array}{l}1 \\
4\end{array}$ & $15-20$ \\
\hline 11. & Siničića špilja & SIN & Siničić, Brinje, HRV & $04 / 2012$ & 3 & 24 \\
\hline 12. & Špilja Stražanj & STR & Izvor rijeke Šuice, Tomislavgrad, B\&H & $08 / 2018$ & 2 & 38 \\
\hline 13. & Špilja Suvaja & SUV & Ušljebrke, Kaštel Žegarski , HRV & 08/2016 & 2 & 180 \\
\hline 14. & Tamnica & TAM & Rumin, Hrvace, HRV & $04 / 2018$ & 2 & 20 \\
\hline 15. & Topla peć & TOP & Golubić Žegarski, HRV & $08 / 2016$ & 4 & 34 \\
\hline 16. & Tounjčica & TNJ & Tounj, HRV & $\begin{array}{l}06 / 2012 \\
04 / 2013\end{array}$ & $\begin{array}{l}2 \\
1\end{array}$ & $32-70$ \\
\hline 17. & $\begin{array}{l}\text { Velika Bukovačka } \\
\text { špilja }\end{array}$ & BUK & Bukovci, Tomislavgrad, B\&H & 08/2018 & 2 & $30-35$ \\
\hline 18. & Velika peć & VEP & Gornji Čabrići, Golubić Žegarski, HRV & $\begin{array}{l}06 / 2012 \\
04 / 2013\end{array}$ & $\begin{array}{l}1 \\
1\end{array}$ & $20-26$ \\
\hline \multicolumn{7}{|c|}{ Additional caves (used for determining Centropyxis bipilata sp. nov. biogeography) } \\
\hline 19. & Čakovac & ČAK & Bobići, Kosinj, HRV & $08 / 2016$ & 1 & 13 \\
\hline 20. & Horvatova špilja & HOR & HE Sklope, Kosinj, HRV & $08 / 2016$ & 1 & 75 \\
\hline 21. & Hukavica & HUK & Donja Vidovska, Velika Kladuša, B\&H & $06 / 2019$ & 1 & 18 \\
\hline 22. & Kotluša & KOT & Kotluša, Vrlika, HRV & 06/2011 & 1 & 35 \\
\hline 23. & Miljacka II & MLJ & Canyon of river Krka, Oklaj, HRV & $07 / 2018$ & 1 & 85 \\
\hline 24. & Pražina pećina & PRŽ & Mlakvena greda, Kosinj, HRV & $08 / 2016$ & 1 & 12 \\
\hline 25. & Rogovac & ROG & Lović Prekriški, Vivodina, HRV & 05/2019 & 1 & 23 \\
\hline 26. & $\begin{array}{l}\text { Špilja na Crvenom } \\
\text { jezeru }\end{array}$ & CRV & Crveno jezero, Imotski, HRV & 09/2018 & 1 & 10 \\
\hline 27. & Veternica & VET & Medvednica, Zagreb, HRV & $10 / 2011$ & 1 & 380 \\
\hline
\end{tabular}

*The precise coordinates of the caves have not been given in order to prevent illegal collecting of the cave fauna, but they can be obtained from the legal authorities in charge of nature protection.

a plastic bottle containing $40 \mathrm{ml}$ of tap water. The procedure was repeated until the water in the bottle was muddied due to dispersed sediment particles.

Sampling of terrestrial cave sediments (inorganic sediment, bat guano, a mixture of mammalian excrement and inorganic sedi- ment): Samples were collected by plastic spoons and placed in plastic bottles. If water was not naturally present in the collected sediment, tap water was added and the sample was held for 24 hours at a temperature of $4-8^{\circ} \mathrm{C}$. This method was used in order to more successfully isolate individuals from the debris. 


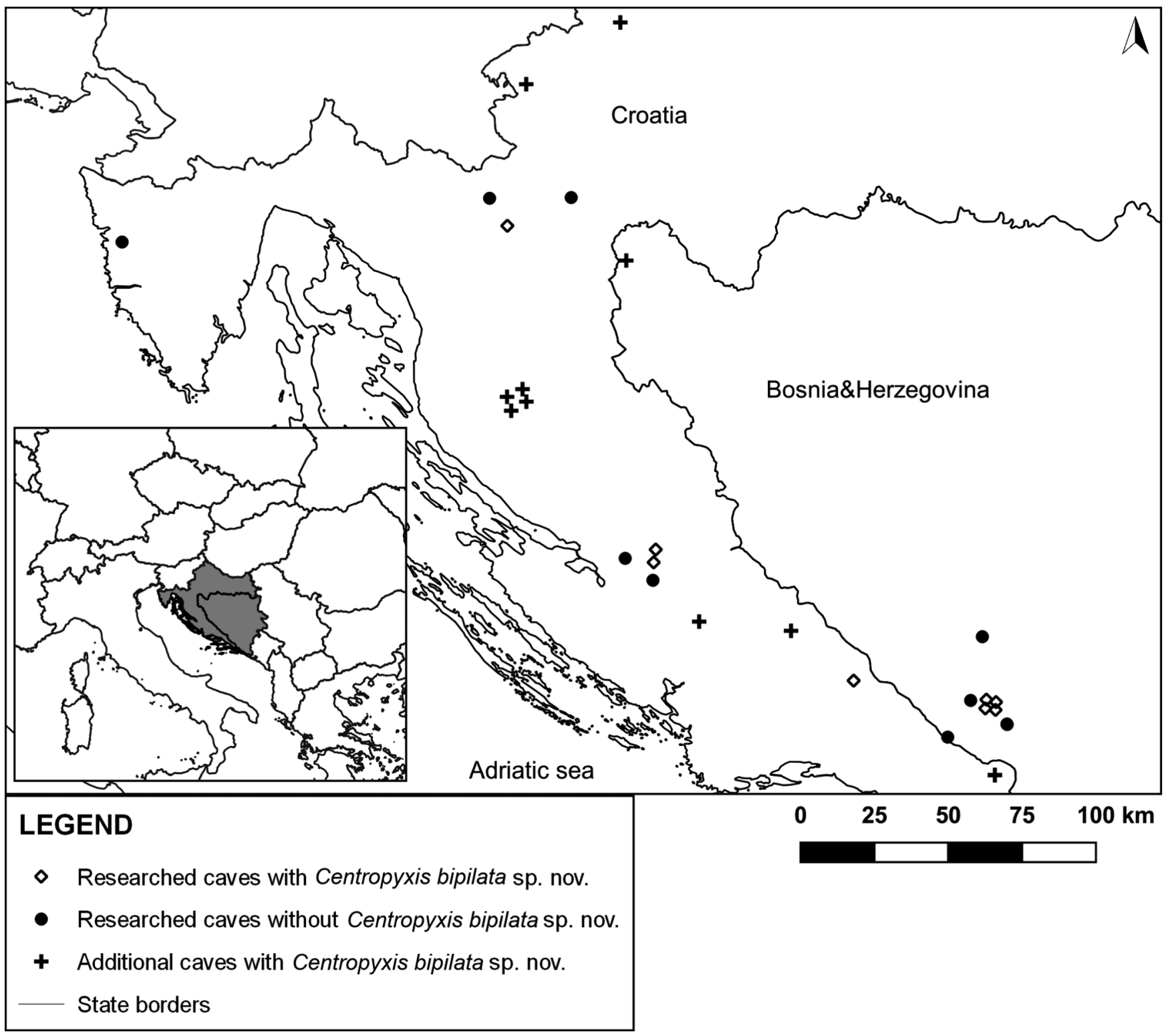

Fig. 1. Cave locations

Sampling of xylal (the source of this wood debris is manmade, or natural water flooding): Samples were collected in plastic bottles along with a small amount of water from the pool in which they were found. A mixture of water and scraped material from the surface of the wood debris was used for examining.

Samples were transported to a laboratory and held at a temperature of $4-8^{\circ} \mathrm{C}$ and were examined within a period of 48 hours from the time of collection. Only in samples from the caves of Velika peć, Jopićeva špilja and Siničića špilja $10 \mathrm{ml}$ of a $4 \%$ formalin solution was added in order to preserve shells of testate amoebae that were present at the moment of sampling. This method was applied because it was not possible to transport the samples on time (within 48 hours) to the laboratory.
Triplets of a volume of $0.2 \mathrm{ml}$ (total $0.6 \mathrm{ml}$ ) were isolated from every sample which consisted of a mixture of sediment / wood debris / mammalian excrement and water. Species were examined using Carl Zeiss Primostar and Carl Zeiss Axiostar light microscopes at magnifications of 100, 400 and 1000 times, and an Olympus BX51 microscope equipped with DIC and phase contrast optics and a Touptek E3ISPM 20MP camera. Adobe Photoshop and ToupView(C) software were used for image processing and measuring.

The presence of phototrophs (cyanobacteria and/or algae) and metazoans in all researched volumes of the samples was also noted and identified to the lowest possible taxonomic levels.

Descriptive statistical analysis was performed with Statistica software and MS Office Excel only for samples from caves 1-18 
(Tab. 1). The geographical map was made in Quantum GIS and it included all prospected caves (Tab. 1).

For the determination of genera and species we used Mazei and Tsyganov (2006), Meisterfeld (2000a, 2000b) and Patterson et al. (2000) as a starting point. In cases of doubt, we used the original descriptions.

\section{RESULTS}

Testate amoebae were detected in $84.6 \%$ of the samples. The total number of species per cave is shown in Fig. 2. The richest biodiversity of testate amoebae was recorded in Ponor Kovači with twenty species.

During this study in 18 caves of the Dinaric arc, 23 species of testate amoebae were identified at the species level (Tab. 2, Fig. 3). Based on their morphological characteristics, four kind of specimens belong to currently undescribed species. All other specimens were identified to the lowest possible category.

The most frequent species with percentage of samples in which they have been found are the following: Trinema lineare (46.2\%), Cryptodifflugia oviformis (32.7\%), Centropyxis bipilata sp. nov. (25.0\%), Cyphoderia ampulla (15.4\%), Centropyxis aerophila, Euglypha cf. rotunda and Trinema enchelis (all three $13.46 \%)$ and Plagiopyxis declivis (11.5\%). Other species appeared in less than $10 \%$ of the samples.

The relation between the numbers of species of different groups of protozoa in the samples from the researched microhabitats is shown in Fig. 4 (excluding samples that were fixed with formalin). These data show that testate amoebae are a dominant group within the protozoa assemblages in the researched samples, although they were not always detected.

Most of the specimens found during this research were only detected as empty tests, but live individuals were also found. For some specimens it was not possible to determine whether they were alive or just empty tests because of the specific opacity of the test due to the presence of opaque mineral particles.

Division in Trinema spp., Cryptodifflugia oviformis, Paraquadrula irregularis, Cyphoderia ampulla and Euglypha spp. was observed several times. Cysts within the shells of Paraquadrula, Euglypha and Heleopera were also noted.

In $24.4 \%$ of the samples (excluding those from the Jama Baredine show cave and samples in the formalin solution) phototrophic organisms such as algae (mostly diatoms) and/or cyanobacteria have been found. The presence of microphototrophs was not detected in all samples from the same cave, but varied on the hydrological conditions before the sampling and specific microhabitat in the cave. Microphototrophs were present in the caves that were exposed to occasional flooding mostly during the winter months (Ponor Kovači, Bilobrkova špilja, Tounjčica cave system, Velika Bukovačka, Stražanj) and in a cave that was not exposed to flooding (Velika peć). Microphototrophs were also detected in one out of three samples from the Jama Baredine show cave.

Meiofauna (Nematoda, Gastrotricha, Rotifera, Oligochaeta, Hydracarina) and insect larvae have also been found in $31.8 \%$ of the samples.

\section{Taxonomic actions}

Centropyxis bipilata sp. nov. (Fig. 5)

urn:1sid:zoobank.org:act:BFDF2F53-30E3-4450B88B-F8EBB7DB85D5

Description: In dorsal view, the test is rounded and usually slightly wider than long; in lateral view, the height of the test is more or less half $(0.4-0.6)$ of the diameter of the test. The dorsal part gradually lowers towards the anterior side, the ventral surface is flattened. The test is built of granular organic cement, yellowish to brown, more or less embedded with small mineral particles. Some tests lack these xenosomes, others are more densely covered. The test never bears spines. The aperture is eccentric, invaginated and ovoid, elliptical or circular. The distance from the centre of the aperture to the anterior edge is approximately $0.4(0.37-0.46)$ of the test length. The edge of the pseudostome curves inward, creating a small but clear ring that is usually slightly darker than the rest of the test. The anterior part of the edge is higher and always connected to the inner anterior-dorsal wall by two struts. Between those struts there is a more or less U-shaped opening, the size of which is variable per specimen, usually large, but sometimes smaller (Fig. 5). Lobopodia as common for this genus. Nucleus not observed.

Dimensions: Length of the test $52-81 \mu \mathrm{m}( \pm 61.7 \mu \mathrm{m})$; width 55-75 $\mu \mathrm{m}( \pm 63.0 \mu \mathrm{m})$; height $28-43 \mu \mathrm{m}$; diameter of the pseudostome $12-22 \times 11-25 \mu \mathrm{m}( \pm 17.2$ $\times 17.8 \mu \mathrm{m})(\mathrm{n}=29)$.

Ecology: Centropyxis bipilata sp. nov. inhabits sediments in aquatic and terrestrial habitats and transitional habitats in freshwater karst caves in Croatia and Bosnia and Herzegovina. It is common in habitat whose energy input is dependent on the seeping water from the surface, on exogenous flooding and on the habitats 
206 N. Baković et al.

Table 2. Biodiversity of testate amoebae in all sampled caves

\begin{tabular}{|c|c|}
\hline Species & Caves where species was observed \\
\hline Arcella sp. & STR \\
\hline Assulina muscorum Greeff, 1888 & LIS, TAM \\
\hline Centropyxis aerophila Deflandre, 1929 & DAH, JOP, KOV, LIS, LTV STR, TAM \\
\hline Centropyxis constricta (Ehrenberg, 1841) Penard, 1890. & SIN, TAM \\
\hline Centropyxis elongata (Penard, 1890) Thomas, 1959 & BAR, KOV, TOP \\
\hline Centropyxis plagiostoma Bonnet \& Thomas, 1955 & TAM, VEP \\
\hline Centropyxis bipilata sp. nov. & $\begin{array}{l}\text { BIL, DAH, CRV, ČAK, HOR, HUK, KOT, KOV, LIS, LTV, MLJ, PRA, ROG, } \\
\text { TAM, TNJ, TOP, VEP, VET }\end{array}$ \\
\hline Centropyxis spp. & DAH, LIS, SUV \\
\hline cf. Conicocassis sp. & BUK, LIS \\
\hline Cryptodifflugia oviformis Penard, 1902 & BIL, DAH, JOP, KOV, LTV, STR, SUV, TAM, TNJ, TOP, VEP \\
\hline Cyclopyxis eurystoma Deflandre, 1929 & BAR, KOV, TAM, TOP \\
\hline Cyclopyxis spp. & BAR, DAH, KOV, LIS, SIN, STR \\
\hline Cyphoderia ampulla Ehrenberg, 1840 & BAR, BUK, DAH, JOP, KOV, LTV \\
\hline Difflugia cf. brevicolla Cash \& Hopkinson, 1909 & KOV \\
\hline Difflugia lithophila Penard, 1902 & $\mathrm{KOV}$ \\
\hline Difflugia oblonga Ehrenberg, 1838 & BAR, KOV \\
\hline Difflugia pristis Penard, 1902 & TAM \\
\hline Difflugia pyriformis Perty, 1849 & BAR, KOV, VEP \\
\hline Difflugia spp. & BUK, JOP, KOV, VEP \\
\hline Diplochlamys sp. & $\mathrm{KOV}$ \\
\hline Euglypha bryophila Brown, 1911 & BUK, KOV \\
\hline Euglypha cf. laevis (Ehrenberg, 1832) Perty, 1849* & DAH, TAM \\
\hline Euglypha $\mathrm{cf}$. rotunda Wailes, $1915^{*}$ & BUK , DAH, JOP, KOV, SUV, TNJ, TOP \\
\hline Euglypha sp. & BAR, TAM, TNJ, VEP \\
\hline Frenzelina sp. Penard, 1902 & TOP \\
\hline Heleopera petricola Leidy, 1879 & VEP \\
\hline Heleopera sp. & JOP \\
\hline Lacogromia sp. & $\mathrm{KOV}$ \\
\hline Meisterfeldia cf. vanhoornei (Beyens et Chardez, 1986) Brobov, 2016 & TOP \\
\hline Microchlamys patella (Claparède et Lachmann, 1859) Cockerell, 1911 & KOV, LTV, STR, VEP \\
\hline Paramphitrema sp.** & $\mathrm{DAH}$ \\
\hline Paraquadrula irregularis Wallich, 1863 & JOP, LTV \\
\hline Parmulina cyathus Penard, 1902 & VEP \\
\hline Plagiopyxis declivis Bonnet, 1955 & JOP, KOV, STR, VEP \\
\hline Plagiopyxis sp. & TAM \\
\hline Pseudodifflugia sp. & TOP, VEP \\
\hline Tracheleuglypha dentata Deflandre, 1928 & DAH, TNJ, TOP \\
\hline Trinema complanatum Penard, 1890 & BAR, SUV \\
\hline Trinema enchelys Ehrenberg, 1838 & BAR, KOV, SUV, TAM, TNJ, TOP, VEP \\
\hline Trinema lineare Penard, 1890 & BAR, BIB, BUK, DAH, DOB, KOV, SIN, STR, SUV, TAM, TOP, VEP \\
\hline Testacea spp.** & BAR, DAH, JOP, LIS, TNJ, SIN, TAM, TOP, VEP \\
\hline
\end{tabular}

*Species identification can only be confirmed by using SEM.

**(Generic) identification can only be confirmed by living specimens. 


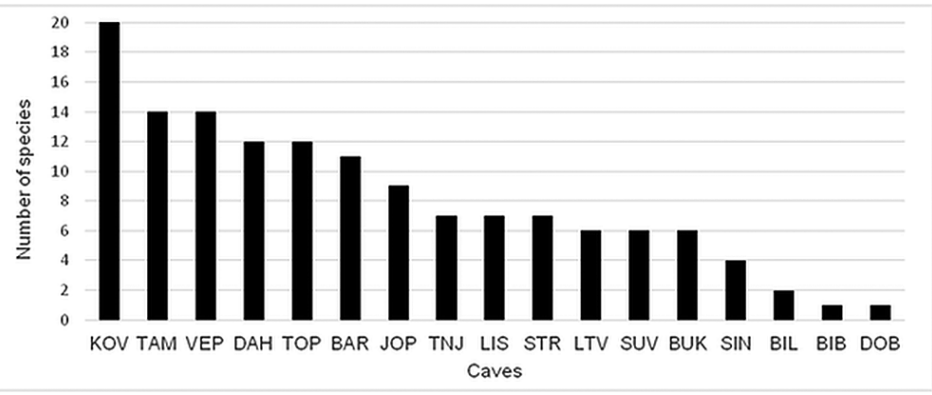

Fig. 2. Total number of detected testate amoebae per cave
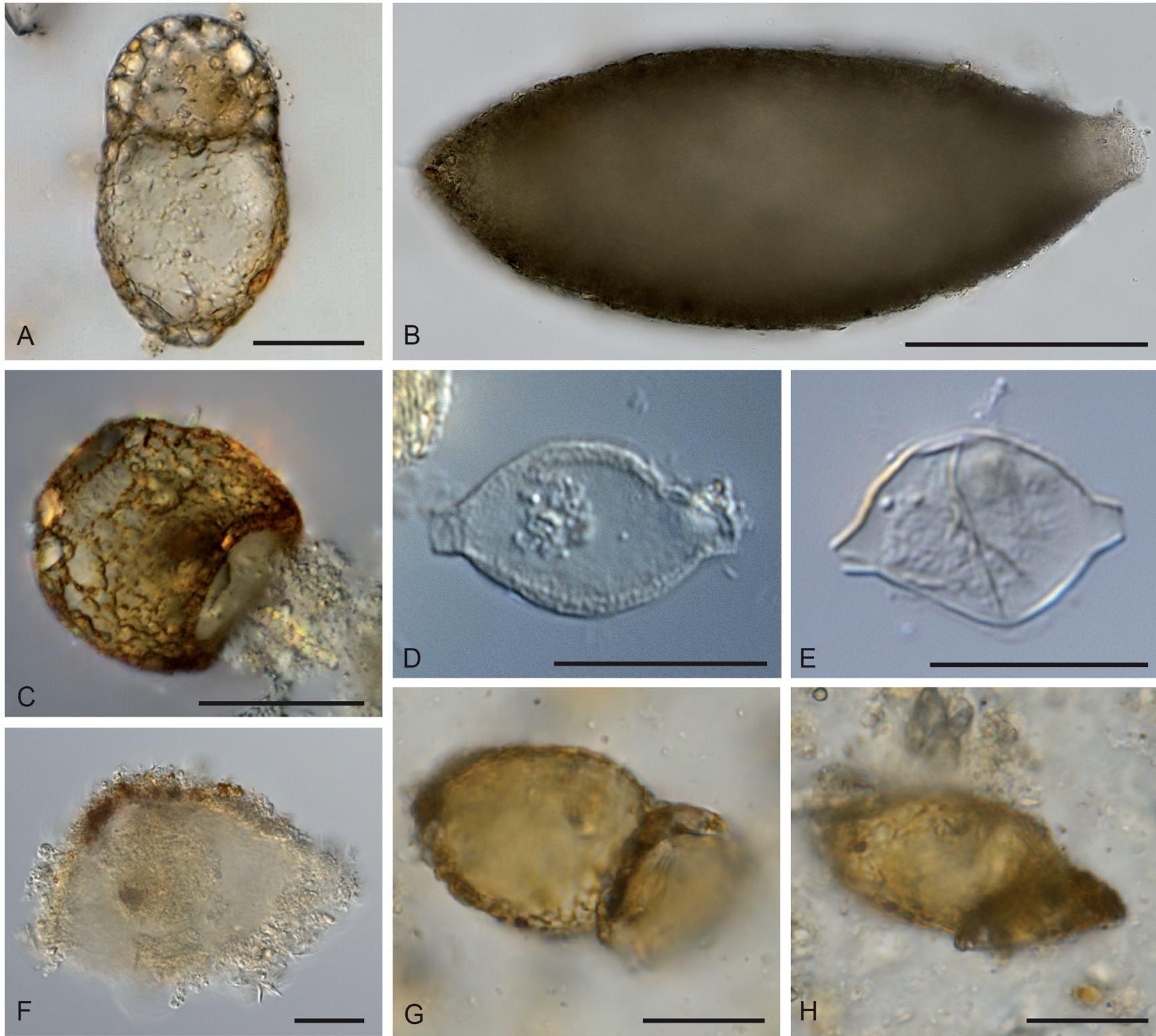

Fig. 3. Examples of species found during this research (A. Centropyxis elongata; B. Lacogromia sp.; C. Cyclopyxis sp.; D-E. Paramphitrema sp.; F. Diplochlamys sp.; G-H. cf. Conicocassis sp.; Scale bars B $100 \mu \mathrm{m}$, all other $20 \mu \mathrm{m}$ ) 

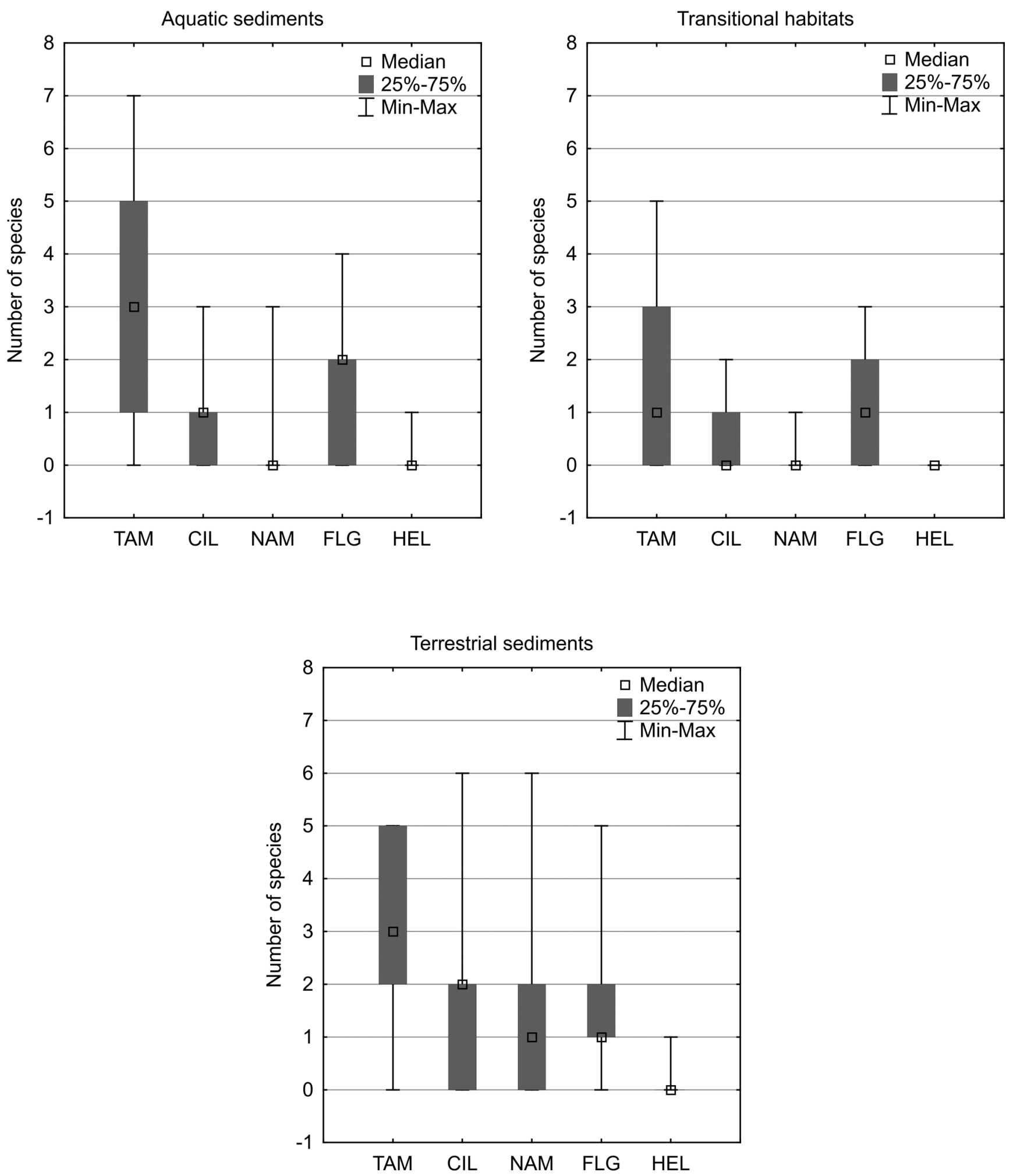

Fig. 4. Biodiversity of protozoa in various cave habitat types (TAM - testate amoebae, CIL - ciliates, NAM - naked amoebae, FLG - heterotrophic flagellates, HEL - heliozoans) 

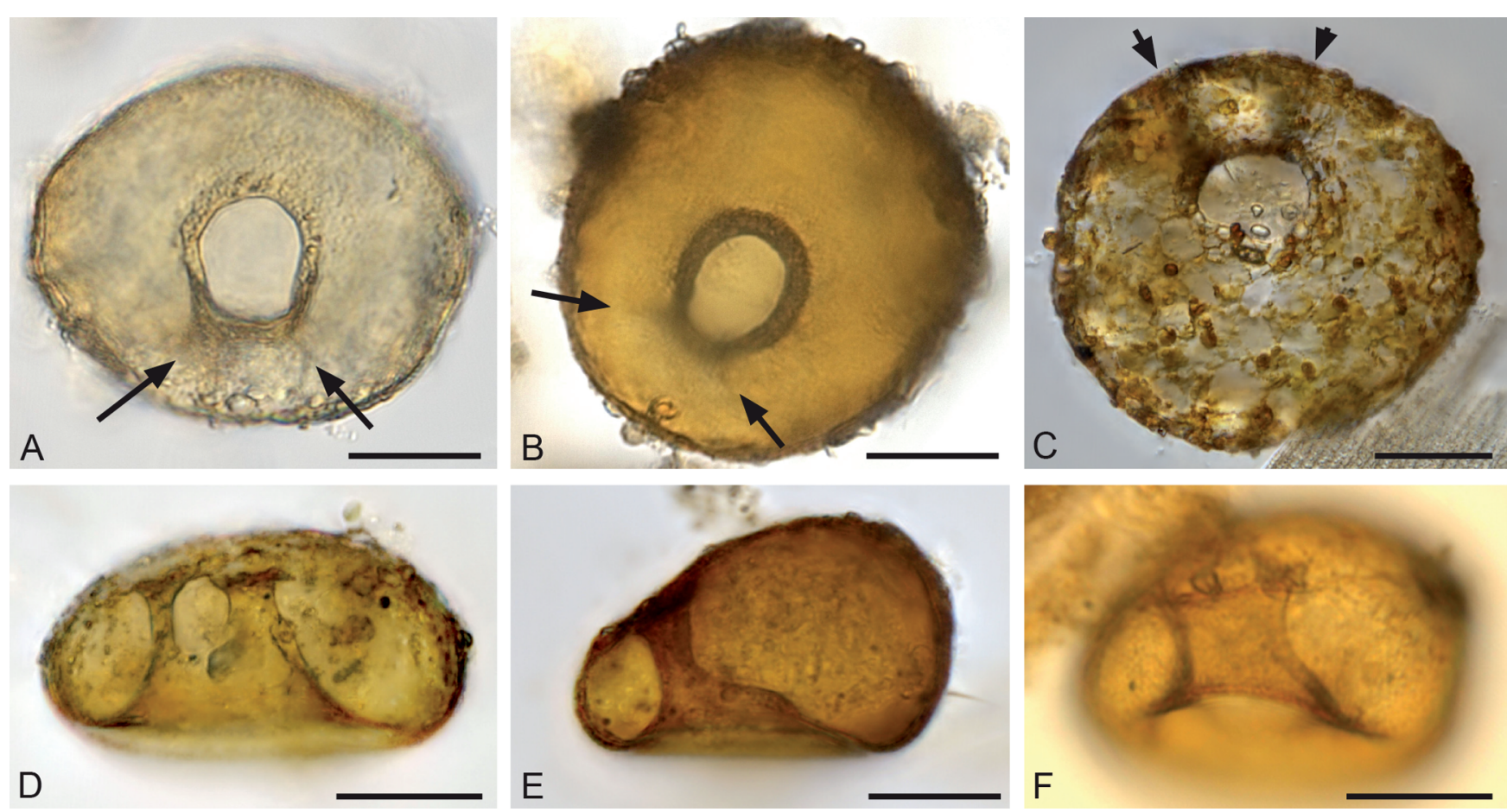

Fig. 5. Centropyxis bipilata sp. nov. A-C. Ventral view, arrows point to the position of the struts; D, F. Frontal view, showing the two struts connected to the dorsal part; E. Side view, showing one strut. A, C-E stacked images. Scale bars: $20 \mu \mathrm{m}$.

that where additionally enriched with bats guano. All habitats, where this species was found, are out of the reach of the sunlight during the whole year. The recorded temperature on habitats of this species ranges from $18^{\circ} \mathrm{C}$ (e.g. Topla peć) to $4.1^{\circ} \mathrm{C}$ (e.g. Veternica cave).

Etymology: bi [from Latin bis] = two; pilata [from Latin pila $]=$ pillar; bipilata refers to the two struts inside the shell.

Type locality: Topla peć, Golubić Žegarski, Croatia

Topla peć is a karst cave formed within a canyon of the river Krupa near the settlement of Golubic Žegarski (Croatia). It is a cave of simple morphology. The entrance is $4 \mathrm{~m}$ high and $4 \mathrm{~m}$ wide and exposed to sunlight from the south. The total length of the cave is $46 \mathrm{~m}$. The entrance channel is $13 \mathrm{~m}$ long and $6 \mathrm{~m}$ high, then narrows to dimensions of $1 \times 2 \mathrm{~m}$ and gives access to a main hall with dimensions of $12 \times 12 \mathrm{~m}$. The cave has a relatively small number of speleothems (Rnjak 2014).

Type specimens: Holotype and paratypes were mounted in HYDRO-Matrix $\subset$ on glass slides and deposited in the Croatian Biospeleological Society Collection under the accession number TAM1 (holotype), TAM2 and TAM3 (paratypes).
Differential diagnosis: Centropyxis bipilata sp. nov. resembles Centropyxis laevigata in general view. However, in C. laevigata the inner and the anterior wall of the shell are connected by a broad flange covered with thick amorphous scales and the test is larger (70-150 $\mu \mathrm{m}$ (Penard, 1902). Schönborn et al. (1983) described a similar species from different locations in Germany as C. laevigata, but their species always had three struts. C. bipilata differs from Centropyxis malvinensis that has the same size and apertural border but two lateral flanges in the middle part (Vucetich, 1975). It can also be distinguished from Centropyxis obscurus that doesn't have a clear rim around the aperture nor any struts (Chardez, 1990). It differs from Centropyxis delicatula that is smaller, has a variable number of 3-5 struts and no pronounced apertural rim (Penard, 1902).

Biogeography: The Dinaric karst area (Mihevc et al., 2010) and isolated mountain karst area in the northern part of Croatia (Lacković et al., 2011).

Centropyxis bipilata sp. nov. has not been detected in the surface habitats close to the researched caves (data not shown within this research), even though surface habitats have not been systematically studied yet. 


\section{DISCUSSION}

\section{Taxonomy}

We could not identify each specimen at the species level. If in doubt, we chose to label specimens as cf. or only at a higher (generic) level. The problem is that traditional taxonomy is primarily based on the morphology of empty tests. However, some tests can only be identified with certainty if pseudopodia have been observed (Meisterfeld 2000a,b; Lara et al. 2007; Mazei and Tsyganov 2006). Correct identification is also hampered by the fact that tests of some Difflugia species are very similar to those of some Pseudodifflugia species. The same applies to tests of Phryganella and Cyclopyx$i s$ species. This makes it difficult to make reliable lists of species and to compare them with the results of other researchers (Kosakyan et al. 2016).

Concerning Centropyxis bipilata sp. nov., the three most important morphological features (shell size, the presence of two struts and the (dark) ring around the aperture) that distinguish this species from all described species with a more or less similar phenotype (see Differential diagnosis) seem very clear. However, we do not know how stable these characters are, in other words: how large the natural variation of shell formation is within this new species. Mayr (1969) wrote that the underestimation of individual variation may have caused more than $50 \%$ of all synonyms. Variation in shell morphology can be caused by environmental influences. For example, Heal (1963) found that the size of Nebela species increased when wet Sphagnum was experimentally flooded and Booth et al. (2010) demonstrated that the number of pores in Hyalosphenia papillio depends upon the water-table depth. Wanner (1994) showed in his experiments that temperature and food influenced the size of the shell of Cyclopyxis kahli. However, in all observed specimens of $C$. bipilata sp. nov., in populations from different caves, the three aforementioned characters were very constant. To illustrate, there were always two struts present, in contrast to $C$. delicatula which has a variable number of struts (Penard, 1902).

These constant morphological characteristics could be a consequence of constant conditions in the caves investigated.

The only constant environmental factor at all locations where Centropyxis bipilata sp. nov. was found is the absence of light. The absence of light has triggered several evolutionary adaptations of cave animals such as loss of eyes and pigments in many species (Culver and Pipan 2009), but these adaptations have evolved in combination with spatial isolation from the surface and other biotic and abiotic factors. On the other hand, intensive surface-subsurface connectivity in karst most likely prevents isolation of subterranean populations of microorganisms in opposition to troglobionts whose ancestors have become extinct from the surface habitats. Many species of soil testate amoebae are living in low-light environments, but they have also been observed in the lighted habitats. The aforementioned spatial variability in caves where Centropyxis bipilata sp. nov. was found implies that some variability in cave environmental conditions is most surely present (with the exception of the absence of light). Considering the distance between caves where $C$. bipilata $\mathrm{sp}$. nov. was found, and also the variability between the environmental conditions, it seems that the morphological characteristics of this species are quite uniform, and not a consequence of isolated conditions at a single location that could trigger a deviation from the phenotype of the already described species.

Even though the currently observed morphological characteristics of Centropyxis bipilata sp. nov. clearly distinguish this species from all the described species, the full extent of its morphological variability should be investigated in the future.

\section{Biogeography}

Among the twenty-three species identified during this research, twelve have not been recorded in karst caves so far according to the check list provided by Mazei et al. (2012). A finding of new but already described species is not surprising since karst subterranean habitats have been investigated very poorly and unsystematically. Also, the South-Eastern region of Europe is poorly investigated. Similar results were shown in research of ciliates in karst caves in Italy, where over 100 species were recorded and half of which were new to the Italian microfauna checklist (Coppellotti Krupa and Guidolin 2003).

Many specimens that have not been identified at the species level imply the possibility that at least some of them may belong to rare species or forms, but also to a new species that should be confirmed by future research. During this research, four species were detected that belong to currently undescribed species. An interesting finding was Centropyxis bipilata sp. nov. that was recorded in several caves in the Dinaric arc, but also in one cave from isolated karst areas on Mt. Med- 
Table 3. Biometric characterization of Centropyxis bipilata sp. nov. based on 29 specimens from three different caves. All measurements are in microns.

\begin{tabular}{llllll}
\hline Sampling location & \multicolumn{2}{c}{ Test } & \multicolumn{2}{c}{ Aperture } \\
\hline & Length & Width & Height & Length & Width \\
Tamnica & $52.2-81.0$ & $58.8-74.8$ & $28.0-42.7$ & $12.6-19.9$ & $11.1-20.1$ \\
Average: & 61.7 & $66.2(\mathrm{n}=13)$ & $35.7(\mathrm{n}=7)$ & $17.7(\mathrm{n}=13)$ & 17.8 \\
Topla peć & $53.1-66.6$ & $55.0-66.5$ & $27.5-33.5$ & $13.7-21.8$ & $13.7-22.5$ \\
Average: & 59.4 & $59.5(\mathrm{n}=12)$ & $30.1(\mathrm{n}=3)$ & $17.6(\mathrm{n}=12)$ & 19.0 \\
Tounjčica & $54.6-72.1$ & $56.5-68.5$ & 35.7 & $16.0-20.9$ & $18.7-24.6$ \\
Average: & 62.2 & $63.1(\mathrm{n}=4)$ & $35.7(\mathrm{n}=1)$ & 19.5 & $21.3(\mathrm{n}=4)$ \\
\hline
\end{tabular}

vednica in the northern part of Croatia (Fig. 1). This data implies a much wider distribution of this species in this region. Another interesting finding was an unknown Lacogromia species, a freshwater foraminifer and the first record from a cave. Until now, freshwater foraminifera have only been known from deep lakes and shallow stagnant oligo- and mesotrophic water types with a layer of organic debris (Siemensma et al. 2017). The presence of a number of empty tests of a Paramphitrema species was also an interesting result. However, the absence of any information about nucleus and type of pseudopodia made it impossible to describe it as a new species.

Individuals not identified to the species level were also encountered by other authors (Decloitre 1955; Gittleson and Hoover 1969, Mazei et al. 2012), but these findings were not interpreted as significant. Some new species and forms of protozoa were also described from subterranean karst habitats (Chibisova 1967, Decloitre 1955, Delhez and Chardez 1970, Matjašič 1962, Vandel 1965, Walochnik and Mulec 2009). Some of them have later been found outside of caves which is the case with Allovahlkampfia spelaea (Tolba et al. 2016, Walochnik and Mulec 2009).

The presence of species only found in caves, but not in the surface habitats of the researched region, is discussed in a paper from Italy and the Volga region (Mazei et al. 2012). This can contribute to our understanding of problems with the testate amoebae biogeography (Foissner 2007) as the caves represent an extra niche for these species. The results of our research and the conclusions of other research (Golemansky and Bonnet 1994, Mazei et al. 2012) indicate that connectivity in the karst, characterized by rapid drainage of underground water, is causing constant input of surface communities into caves. It means that a possible precondi- tion for speciation in caves - spatial isolation (Riesch et al. 2011) is not fulfilled. On the other hand, findings of Centropyxis bipilata sp. nov., imply that we need to further investigate whether this species is a true cavedweller or typical for this geographical region (both in surface and subsurface habitats). This species was also found in $25.0 \%$ of the collected samples in this research, and it is surprising that it was not found by any other researcher. The described morphology of C. bipilata $\mathrm{sp}$. nov. would be easily noticed, especially by skilled protozoologists who very carefully studied morphometric data of individuals from caves such as Decloitre (1955) and Chibisova (1967) but also by newer data that also included SEM imaging (Mazei et al. 2012).

The dominance of already described and mostly eurybiont species of testate amoebae found by other researchers (Gittleson and Hoover 1970, 1969; Golemansky and Bonnet 1994; Vandel 1965) together with emphasizing the easy transfer from the surface habitats was the most frequently accentuated conclusion. For this reason, the current results have not triggered further research. Expressing the fact that the diversity of testate amoebae is determined by the surface habitats and that individuals are transferred into caves from the surface, could easily be interpreted that there are no communities living in caves and shaping their food networks. But what is then supporting the communities of cave organisms?

True cave animals (vertebrates and invertebrates) exhibit a remarkable physiological, morphological and behavioural adaptation to their environment (Culver and Pipan 2009, Pricop and Mihai 2009, Romero Jr 2009). With other abiotic factors that triggered the evolution of cave animals (such as absence of light, stable temperature and humidity, spatial isolation, etc.) the availability, composition and variation of their food sources 
should be determined as equally important. It should not be forgotten that, due to the absence of primary phototrophic production in caves, surface habitats are the main importers of organic material into these ecosystems (Simon et al. 2007) with the exception of chemoautotrophic subterranean ecosystems not discussed here (Engel 2010). Microorganisms (including protozoa) are the first consumers of this organic material, but they also serve as a food source for other organisms. Data gathered during this research show the presence and variation of the biodiversity of protozoa in various habitats (Fig. 4). As all the researched samples were examined within 48 hours, it is positively certain that these organisms are integral members of subterranean food networks. Testate amoebae show quite rich biodiversity compared to other groups of detected organisms. This could be partially attributed to the resistance of their tests that can be detected even if the organism has died. It also implies that the temporal biodiversity of other groups of protozoa in caves (ciliates, naked amoebae, heliozoans) could also be much richer. A summary of the testate amoebae biodiversity per cave (Fig. 2) shows relatively rich biodiversity of some locations such as Ponor Kovači. If we consider that these are results based on a small number of samples and a small number of researched habitats, the biodiversity of testate amoebae could be much richer. When discussing findings of testate amoebae in this research, it is important to respect the fact that testate amoebae, compared to other groups of protozoa in karst caves, have additional features that can be used to interpret the results - very resistant tests that could give us 'echo data' about potential variations of their biodiversity and abundance in these habitats. For this reason, the results on the biodiversity of testate amoebae compared to other groups of protozoa (Fig. 4) should be interpreted with caution.

There are several arguments in favour of the fact that the populations of testate amoebae in the subterranean habitats of the Dinaric arc, presented in this research, are at least partially independent of the above-ground populations: the size of the individuals compared to the surface species composition, indicative presence of microphototrophs and individuals in the process of division.

Among the recorded testate amoebae in this research, smaller and medium sized species are dominant (Tab. 2) referring to literature data. On the other hand, surface communities of testate amoebae (not shown in this research) in drainage regions of the researched caves of the Dinaric karst include varieties of habitats that are inhabited with typical larger species of Nebelidae, Hyalospheniidae, Difflugiidae, Euglyphidae, Centropyxiidae etc. that were not found during this research.

Physical sedimentation of testate amoebae is possible starting from the surface soil layers where, due to the small spaces between the soil particles, it is most intensive. Also, it should not be ignored that the distribution of testate amoebae in soil is specific, depending on the depth and other factors (Vincke et al. 2006). The epikarst is the upper layer of bedrock with an extensive net of cracks formed by the combination of microtectonics and intensive dissolution processes in carbonate rocks and it is partially filled with sediment in the upper layers (Klimchouk 1995, Williams 2008). In the epikarst water is traveling through a series of small fissures that can allow much faster transport of individuals by water due to a smaller amount of sediment or his complete absence. After the epikarst, the transport of water in bedrock is going through a smaller number of wider channels formed in the bedrock. The relationship between soil layer, epikarst and bedrock structure can vary significantly in carbonate rocks (Bakalowicz 1975, Klimchouk 1995). Having such a long path from the surface to the cave that includes soil and bedrock can definitely decrease the possibility of direct transport of individuals from the surface, but this percentage can vary from cave to cave depending on the above-mentioned conditions. Gittleson and Hoover (1969) also discussed this issue by stating that the small size of protozoa found in caves is the consequence of their filtration through the crevasses of the sandstone and limestone. They have attributed the findings of larger species only to the situations in which the filtration was not involved or was involved to a lesser extent. At that time, very little data was known about the communities living in the epikarst, so these were not included in the discussions.

The epikarst harbours exceptionally rich aquatic fauna. The most studied group is the Copepoda with numerous troglobiotic species that very often have a highly endemic distribution (Pipan 2005, Pipan and Culver 2007). So the testate amoebae that were gravitationally pulled into the epikarst layer by rain water are imported into an environment inhabited with organisms that will feed on them. Testate amoebae will also feed on available food in the epikarst such as bacteria (Pipan et al. 2004). The differences between the cave and aboveground populations noticed in our research (prevalence of small and medium sized species; variable presence of phototrophic organisms) could also be a consequence 
of biotransformation of the communities in the epikarst zones. It is known that predation pressure can modify the morphometric characteristics within the population of protozoa (Kołaczyk and Wiackowski 1997) and change the composition of the species. For example, the absence of larger species (such as Nebelidae) can be a consequence of a lower presence of phototrophic organisms that are an important part of their diet.

This biotransformation is especially important for protozoa, because they are not strictly limited to photic habitats. In the case of mixotrophs, there is a noted case of findings of individuals that shifted fully to a heterotrophic diet such as Euglena viridis (Gittleson and Hoover 1969, Vandel 1965), so their transformation (losing chromoplasts) is obvious. On the other hand, phototrophic organisms, even if they survive some time, are destined to extinction in an aphotic environment.

The fact that the transfer of protozoa-sized organisms from the surface to the karst aquifer is possible is shown by the experiment carried out by Harvey et al. (2008) on the example of Cryptosporidium parvum, so this is not debatable. An addition indicator that direct transport from the surface to the cave is possible, shown in this research, is the presence of microphototrophs in $24.4 \%$ of the collected samples. Phototrophic organisms, during this study, were mostly found in habitats that were exposed to occasional flooding by exogenous and endogenous waters. Occasional flooding implies fast inflow of surface water into the cave (Bonacci 1987 , White 1988), so it is possible that turbulent waterflow through large channels could, together with microphototrophic organisms, import testate amoebae into caves as well.

One out of three samples from the show cave Jama Baredine illuminated from spring to autumn contained microphototrophs. The presence of phototrophs in this cave could be attributed to 'lampenflora' or 'la maladie verte' (White and Culver 2012).

The presence of microphototrophs in caves (excluding lampenflora) was mentioned by some authors (Falasco et al. 2014, Gittleson and Hoover 1969, Golemansky and Bonnet 1994), but almost nothing is known about their ecology in the context of subterranean habitats with the exception of lampenflora primar producers (Mulec 2018, Mulec et al. 2008) and phototrophic communities in cave entrances (Martínez and Asencio 2010, Popović et al. 2015).

Considering the resistance of diatomaceous tests (made of silica) and the well-known ability of many phototrophs to survive periods of time in the absence of light on a heterotrophic diet (Lee 2008), it is unusual that they are not found more often in caves. Phototrophic organisms were not found in all samples from individual caves (e.g. Ponor Kovači and Tounjčica) implying that their presence is spatially and temporally variable. This can be explained if we consider the small volumes of investigated samples in this research methodology (only $0.6 \mathrm{ml}$ of samples was examined) so it cannot be excluded that they could be present, but in smaller densities which may explain that they were found in only $24.4 \%$ of the samples. This topic is especially important if we want to discuss the ecological importance of the composition and availability of food for the subterranean fauna.

During this study, very often specimens were encountered that were in the process of binary division indicating the active reproduction of these individuals in caves. This means that newcomers - testate amoebae that have been flushed into the caves - are coming to a habitat that has already been inhabited by other organisms. The interesting question to be answered in the future is: how are these events, that bring newcomers into the caves, influencing the already established testate amoeba populations in the caves?

\section{CONCLUSION}

This research showed that caves in the Dinaric arc are mostly inhabited by previously described and common species that are in accordance with the findings of other researchers. Nevertheless, the detection of previously described species that have not yet been found in caves indicates that the regional biodiversity in caves could be more diverse than previously thought.

Findings of Centropyxis bipilata sp. nov., together with other candidates for new species and some rare species, imply that further cave research can provide us with valuable data on the biodiversity of testate amoebae. Even though caves have been recognized as habitats of many animal species that are only distributed in caves, we don't have enough arguments to claim that C. bipilata sp. nov. is an obligate cave dweller. This topic could only be resolved through intensive comparative research of the cave and surface communities of testate amoebae.

Testate amoebae are almost constant members of subterranean protozoa assemblages at all researched habitats, and their biodiversity often exceeds other groups of protozoa. This can be attributed to findings of 
empty tests as we cannot be sure that living individuals are actually present in the researched habitats. The differences in biodiversity between caves can be explained by variable sampling efforts, habitat diversity and hydrological conditions during sampling.

Findings of algae and/or cyanobacteria in some cave habitats have been recognized as very useful indicator of connectivity between surface and cave habitats. The data on the spatial and temporal presence of microphototrophic organisms in caves can help us better understand the significance of impact of surface communities on the already established cave communities of testate amoebae. The full potential of microphototrophs as indicators of connectivity should be investigated by future research.

This research covered a relatively large area, but it was performed on a small number of samples and only included general alpha diversity. Nevertheless, it was revealed that studying protozoa in caves could bring new knowledge about the biology of testate amoebae.

Acknowledgements. We would like to express our gratitude to the members of the following societies that assisted us during field trips: Mijatovi dvori, PDŽ-SO, DDISKIF, Biospeld, Osmica, HBSD and ADIPA. Special thanks to the organizers and supporters of the following international expeditions: Cave-diving expedition Ponor Kovači - izvor Ričine (2013, 2014, 2018), Cave-diving expedition Kamena galaksija (2016), and Interdisciplinary scientific expedition Crveno jezero (Red Lake) (2018). Special thanks to Ms Korana Baković for her technical support during field trips and laboratory work, and Ms Petra Žvorc and Mr Goran Rnjak for some data about Topla peć. This work has been supported in part by the University of Rijeka under project number "uniritechnic-18-298".

This research was performed under permissions of the following legal authorities in Croatia and Bosnia and Herzegovina: Croatian Ministry of Culture (Class: UP/I-612-07/11-33-0882, Ref. No.: 532-08-01-01/1-11-02, 26.08.2011), Croatian Ministry of Environmental and Nature Protection (Class: UP/I-612-07/12-48/30, Ref. No.: 517-07-1-1-1-12-2, 18.09.2012; Class: UP/I-612-07/15-48/19, Ref. No.: 517-07-1-1-1-15-6, 18.06.2015), Croatian Ministry of Environmental Protection and Energy (Class: UP/I-612-07/17-33/03, Ref. No.: 517-07-2-1-2-17-3, 08.03.2017; Class: UP/I-612-07/1948/38, Ref. No.: 517-05-1-1-19-5, 29.03.2019), Federal Ministry of Environment and Tourism (No.: 04-23-7-623/13 ZM, 17.05.2013; No: 04-23-1082/14 ZM, 26.08.2014; No.: 04-23-817/15 ZM, 21.07.2015; No.: 04-23-1057/17, 14.12.2017).

\section{REFERENCES}

Bakalowicz M. (1975) Géochimie des eaux karstiques et karstification. Ann. Spéléologie 30: 581-589

Bobrov A. A. (2019) Planhoogenraadia liboica sp. nov. a new testate amoebae species from mountain forest soils in China. Protistology 13: 64-66

Bonacci O. (1987) Karst hydrology: with special reference to the Dinaric karst. Springer series in physical environment. Springer. Berlin
Booth R. K., Meyers B. (2010) Environmental controls on pore number in Hyalosphenia papilio: Implications for paleoenvironmental reconstruction. Acta Protozool. 49: 29-35

Chardez D. (1990) Thecamoebiens (Rhizopoda, Testacea) des millieux aniso-oligohydriques mousses et lichens. Acta Protozool. 29(2): $147-152$

Chibisova O. I. (1967) Testacea from some caves and karst reservoirs Zool. Zhurnal 44: 181-186 (In Russian).

Coppellotti Krupa O., Guidolin L. (2003) Taxonomy and ecology of ciliate fauna (Protozoa, Ciliophora) from karst caves in NorthEast Italy. Subterr. Biol. 1: 3-11

Culver D. C., Pipan T. (2009) The biology of caves and other subterranean habitats. The biology of habitats series. Oxford University Press. New York

Culver D. C., Sket B. (2000) Hotspots of Subterranean Biodiversity in Caves and Wells. J. Cave Karst Stud. 62: 11-17

Decloitre L. (1955) Thécamoebiens de la grotte des Singes a Ségéa (Guinée). Speleologica africana. Bull. IFAN, Ser. 1.17.: 989-1099

Delhez F., Chardez D. (1970) Protozoaires des Grottes de Belgique. Ann. Spéléologie 25: 107-137

Engel A. S. (2010) Microbial Diversity of Cave Ecosystems, in: Barton L. L., Mandl M., Loy A. (Eds.), Geomicrobiology: Molecular and Environmental Perspective. Springer Netherlands, Dordrecht: 219-238

Falasco E., Ector L., Isaia M., Wetzel C., Hoffmann L., Bona F. (2014) Diatom flora in subterranean ecosystems: A review. Int. J. Speleol. 43(3): 231-251

Foissner W. (2007) Biogeography and dispersal of micro-organisms: a review emphasizing protists. Acta Protozool. 45: 111-136

Foissner W., Galina A., Korganova A. (1995) Redescription of Three Testate Amoebae (Protozoa, Rhizopoda) from a Caucasian Soil: Centropyxis plagiostoma Bonnet \& Thomas, Cyclopyxis kahli (Deflandre) and C. intermedia Kuferath. Arch Protistenkd 146: $13-28$

Gittleson S. M., Hoover R. L. (1970) Protozoa of underground waters in caves. Ann. Speleol. 25: 91-106

Gittleson S. M., Hoover R. L. (1969) Cavernicolous protozoa: review of the literature and new studies of Mammoth Cave, Kentucky. Ann. Speleol. 24: 737-776

Golemansky V. G., Bonnet L. (1994) Protozoa. In: Encyclopaedia Biospeologica, (Eds. Juberthie C., Decu V.). Société de Biospéologie, Moulis, 23-33

Harvey R. W., Metge D. W., Shapiro A. M., Renken R. A., Osborn C. L., Ryan J. N., Cunningham K. J., Landkamer L. (2008) Pathogen and chemical transport in the karst limestone of the Biscayne aquifer: 1. Revised conceptualization of groundwater flow. Water Resour. Res. 44-16

Heal O. W. (1963) Morphological variation in certain Testacea (Protozoa: Rhizopoda). Arch. Protistenk. 106: 351-368

Hoogenaard H. R., De Groot A. A. (1940) Zoetwaterrhizopoden en -Heliozoën. Fauna van Nederland. Sijthoff, Leiden

Klimchouk A. (1995) Karst morphogenesis in the epikarstic zone. Cave and karst science 21(2): 45-50

Kołaczyk A., Wiackowski K. (1997) Induced defence in the ciliate Euplotes octocarinatus is reduced when alternative prey are available to the predator. Acta Protozool. 36(1): 57-61

Kosakyan A., Gomaa F., Lara E., Lahr D. J. G. (2016) Current and future perspectives on the systematics, taxonomy and nomenclature of testate amoebae. Eur. J. Protistol. 55, 105-117

Lacković D., Glumac B., Asmerom Y., Stroj A. (2011) Evolution of the Veternica cave (Medvednica Mountain, Croatia) drainage 
system: insights from the distribution and dating of cave deposits. Geol. Croat. 64: 213-221

Lara E., Heger T. J., Mitchell E. A. D., Meisterfeld R., Ekelund F. (2007) SS SSU rRNA Reveals a Sequential Increase in Shell Complexity Among the Euglyphid Testate Amoebae (Rhizaria: Euglyphida). Protist 158: 229-237

Lee R. E. (2008) Phycology, Fourth ed. Cambridge University Press. New York

Mayr E. (1969) Principles of Systematic Zoology. McGraw Hill, New York

Martínez A., Asencio A. (2010) Distribution of cyanobacteria at the Gelada Cave (Spain) by physical parameters. J Cave Karst Stud. 72(1): $11-20$

Matjašič J. (1962) Nova jamska Folikulinida (Euciliata, Heterotricha) iz Hercegovine. Biol Vestn 10: 49-53 (In Slovenian with German Abstract)

Mazei Yu. A., Belyakova O., Trulova A., Guidolin L., Coppellotti O. (2012) Testate amoebae communities from caves of some territories in European Russia and North-Eastern Italy. Protistology 7: 42-50

Mazei Yu. A., Tsyganov A. (2006) Freshwater testate amoebae KMK, Moscow (in Russian)

Meisterfeld R. (2000a) Testate amoebae with filopodia - The Illustrated Guide to the Protozoa. Allen Press Inc., Lawrence

Meisterfeld R., (2000b) Arcellinida Kent, 1880 - The Illustrated Guide to the Protozoa. Allen Press Inc., Lawrence

Mihevc A., Prelovšek M., Zupan Hajna N. (2010) Introduction to the Dinaric Karst. Karst Research Institute at ZRC SAZU, Postojna

Mitchell E. A. D., Charman D. J., Warner B. G. (2008) Testate amoebae analysis in ecological and paleoecological studies of wetlands: past, present and future. Biodivers. Conserv. 17: $2115-2137$

Mulec J. (2018) Phototrophs in Caves: Analysis and Synthesis. In: Cave Ecology, (ed. Moldovan O. T., Kováč L., Halse S.). Springer, Cham, 91-106

Mulec J., Kosi G., Vrhovšek D. (2008) Characterization of cave aerophytic algal communities and effects of irradiance levels on production of pigments. J. Cave Karst Stud. 70: 3-12

Patterson D. J., Simpson A. G. B., Rogerson A. (2000) The Illustrated Guide to the Protozoa - Amoebae of Uncertain Affinities. Allen Press Inc. Lawrence

Penard E. (1902) Faune Rhizopodique du Bassin de Léman. Kundig, Geneve

Pipan T. (2005) Epikarst - a promising habitat: copepod fauna, its diversity and ecology: a case study from Slovenia (Europe). Karst Research Institute at ZRC SAZU. ZRC Publishing, Postojna-Ljubljana

Pipan T., Culver D. (2007) Epikarst communities: Biodiversity hotspots and potential water tracers. Environ. Geol. 53(2): 265-269

Pipan T., Mulec J., Geric Stare B. (2004) Diversity of culturable bacteria and meiofauna in the epikarst of Škocjanske jame caves (Slovenia). Acta carsologica 33(1): 302-309

Popović S., Subakov Simic G., Stupar M., Unković N., Predojević D., Jovanović J., Grbić M., (2015) Cyanobacteria, algae and microfungi present in biofilm from Božana Cave (Serbia). Int. J. Speleol. 44(2): 141-149

Pricop E., Mihai N. (2009) On the adaptations to cave life of some different animal groups (first note), ELBA Bioflux 1(2): 41-48

Riesch R., Plath M., Schlupp I. (2011) Speciation in caves: experimental evidence that permanent darkness promotes reproductive isolation. Biol. Lett. 7: 909-912

Rnjak G. 2014. Cave map of Topla peć, Krupa, Golubić, Obrovac (national cave cadastre number 07, 0019)

Romero Jr A., 2009. Cave Biology: Life in Darkness. Cambridge University Press. New York

Schönborn W., Foissner W. and Meisterfeld R. (1983) Licht- und Rasterelektronenmikroskopische Untersuchungen zur Schalenmorphologie und Rassenbildung Bodenbewohnender Testaceen (Protozoa : Rhizopoda) sowie Vorschläge Zur Biometrischen Charakterisierung von Testaceen-Schalen. Protistologica 19(4): 553-566

Siemensma F., Apothéloz-Perret-Gentil L., Holzmann M., Clauss S., Völcker E., Pawlowski J. (2017) Taxonomic revision of freshwater foraminifera with the description of two new agglutinated species and genera. Eur. J. Protistol. 60: 28-44

Simon K., Pipan T., Culver D., 2007. A conceptual model of the flow and distribution of organic carbon in caves. J. Cave Karst Stud. 69(2): 279-284

Smith H. G., Bobrov A., Lara E. (2008) Diversity and biogeography of testate amoebae. Biodivers. Conserv. 17: 329-343

Tolba M. E. M., Huseein E. A. M., Farrag H. M. M., Mohamed H. E. D., Kobayashi S., Suzuki J., Ali T. A. M., Sugano S. (2016) Allovahlkampfia spelaea Causing Keratitis in Humans. PLoS Negl. Trop. Dis. 10: 1-10

Vandel A. (1965) Biospeleology: the biology of cavernicolous animals. Pergamon Press, Oxford

Vincke S., Van de Vijver B., Nijs I., Beyens L. (2006) Changes in the Testacean Community Structure Along Small Soil Profiles. Acta Protozool. 45: 395-406

Vucetich M. C. (1975) Tecamebianos muscicolas y esfagnicolas de islas Malvinas (Argentina). Neotropica 21:11-16

Walochnik J., Mulec J. (2009) Free-living amoebae in carbonate precipitating microhabitats of karst caves and a new vahlkampfiid amoeba, Allovahlkampfia spelaea gen. nov., sp. nov. Acta Protozool. 48: 25-33

Wanner M. (1994) Effects of light, temperature, fertilizers and pesticides on shell size of the common freshwater and soil species Cyclopyxis kahli (Rhizopoda, Testacealobosia). Limnologica 24: $333-338$

White W. B., 1988. Geomorphology and hydrology of karst terrains. Oxford University Press, New York

White W. B., Culver D. C. (Eds.), 2012. Encyclopedia of caves, 2nd ed. ed. Academic Press, Waltham, MA.

Williams P. (2008) The role of the epikarst in karst and cave hydrogeology: a review. Int. J. Speleol. 37: 1-10

Received on $30^{\text {th }}$ October, 2019; revised on $13^{\text {th }}$ February, 2020; accepted on $13^{\text {th }}$ February, 2020 